\title{
EVALUASI PROGRAM PEMBELAJARAN PEKERJAAN DASAR TEKNIK OTOMOTIF KELAS X TKRO DI SMK NEGERI 1 SEDAYU
}

\author{
Zhafran Anas \& Agus Budiman \\ Fakultas Teknik, Universitas Negeri Yogyakarta \\ Email: zhafran.nas@gmail.com
}

\begin{abstract}
This research is to find out the Automotive Engineering Basic Work learning program at SMK Negeri 1 Sedayu focused on: context: learning planning; input: teacher, students, and infrastructure; process: media, methods, learning resources, and learning steps; product: student learning outcomes. Includes descriptive CIPP research models (context, input, process, product) evaluation. The results of the study note that the learning program Basic Automotive Engineering Work in SMK Negeri 1 Sedayu in terms of: context: the learning objectives of the PDTO learning program are in accordance with the 2013 Curriculum and not all basic competencies can be conveyed to students; input: PDTO teachers are undergraduate (S1) majoring in Mechanical Engineering Education and have educator certification, student motivation is quite good (46.296\%), good classroom facilities and infrastructure (63.634\%), and PDTO practice tools are very good (86.318\%); process: the use of learning media is quite good (35.185\%), the use of learning media is quite good (37.963\%), the use of learning resources is quite good (37.963\%), and the implementation of learning steps is very good (100\%); product: the percentage of students completeness $41.667 \%$ and $54.630 \%$.
\end{abstract}

Keywords: Evaluation, Learning Program, PDTO, CIPP

\begin{abstract}
Abstrak
Penelitian ini untuk mengetahui program pembelajaran Pekerjaan Dasar Teknik Otomotif (PDTO) di SMK Negeri 1 Sedayu difokuskan pada: context: perencanaan pembelajaran; input: guru, siswa, dan sarana prasarana; process: media, metode, sumber belajar, dan langkah pembelajaran; product: hasil belajar siswa. Termasuk penelitian deskriptif model CIPP (context, input, process, product) evaluation. Hasil penelitian diketahui bahwa program pembelajaran Pekerjaan Dasar Teknik Otomotif di SMK Negeri 1 Sedayu dari aspek: context: tujuan pembelajaran program pembelajaran PDTO sesuai dengan Kurikulum 2013 dan belum semua kompetensi dasar dapat tersampaikan kepada siswa; input: guru PDTO adalah sarjana (S1) jurusan Pendidikan Teknik Mesin dan memiliki sertifikasi pendidik, motivasi siswa cukup baik (46,296\%), sarana dan prasarana kelas baik $(63,634 \%)$, dan alat praktik PDTO sangat baik $(86,318 \%)$; process: penggunaan media pembelajaran cukup baik $(35,185 \%)$, penggunaan media pembelajaran cukup baik $(37,963 \%)$, pemanfaatan sumber belajar cukup baik (37,963\%), dan keterlaksanaan langkah pembelajaran sangat baik $(100 \%)$; product: persentase ketuntasan siswa $41,667 \%$ dan $54,630 \%$.
\end{abstract}

Kata kunci: Evaluasi, Program Pembelajaran, PDTO, CIPP

\section{PENDAHULUAN}

Pendidikan merupakan wadah untuk menciptakan manusia yang cerdas, terampil, dan berakhlak mulia. Pemerintah Indonesia menyelenggarakan suatu sistem pendidikan dan pengajaran nasional yang diatur dalam Undang-Undang Nomor 20 Tahun 2003 Pasal 3, yang 


\section{Agus Budiman, Zhafran Anas}

menjelaskan bahwa pendidikan nasional berfungsi mengembangkan kemampuan dan membentuk watak serta peradaban bangsa yang bermanfaat dalam rangka mencerdaskan kehidupan bangsa, bertujuan untuk berkembangnya potensi peserta didik agar menjadi manusia yang beriman dan bertakwa kepada Tuhan Yang Maha Esa, berakhlak mulia, sehat, berilmu, cakap, kreatif, mandiri, dan menjadi warga negara yang demokratis serta bertanggung jawab. Dalam Undang-Undang Nomor 20 Tahun 2003, Sekolah Menengah Kejuruan (SMK) merupakan jalur pendidikan formal pada jenjang menengah yang masuk dalam jenis pendidikan kejuruan. Dalam Peraturan Pemerintah Nomor 29 Tahun 1990 Pasal 3, menyebutkan bahwa pendidikan menengah kejuruan mengutamakan penyiapan siswa untuk memasuki lapangan kerja serta mengembangkan sikap profesional.

Namun faktanya, Daerah Istimewa Yogyakarta mengalami peningkatan dalam jumlah angka penganggurannya. Berdasarkan dari laman berita Tribun Jogja, pada tahun 2017 tercatat angka pengangguran sebanyak 63.719 orang dan tahun 2018 meningkat menjadi 73.350 orang. Merunut dari berita tersebut, dalam laman berita Berita Satu, Andung Prihadi selaku Kepala Disnakertrans DIY membenarkan jika digolongkan berdasarkan latar belakang pendidikan, lulusan SMK menjadi penyumbang angka pengangguran tertinggi di DIY. Selain itu berdasarkan laman berita Detik News, Dinas Pendidikan Pemuda dan Olahraga DIY menjelaskan bahwa hasil UNBK untuk jenjang SMK mengalami penurunan nilai rata-rata. Tahun 2016 nilai rata-rata empat mata pelajaran diujikan adalah 253,75 sedang tahun 2017 hanya 245,60. Sejalan dengan itu sebagai mana yang ada dalam laman berita Harian Jogja, pada tahun 2018 di wilayah DIY sendiri, nilai rata-rata empat mata pelajaran yang diujikan pada jenjang SMK adalah 218,04. Kabalitbang Kemendikbud, Totok Suprayitno dalam laman berita Direktorat Jenderal Guru dan Tenaga Pendidikan, hasil UN sebagai cerminan hasil pembelajaran di kelas perlu dianalisa untuk mengetahui faktor-faktor yang mempengaruhi capaian tersebut.

Berdasarkan hasil Ujian Tengah Semester (UTS) Ganjil yang dilakukan pada 17 September 2018 sampai dengan 26 September 2018, dalam mata pelajaran PDTO yang diajarkan ke kelas $\mathrm{X}$ TKRO banyak siswa yang belum memenuhi nilai Kriteria Ketuntasan Minimal (KKM) yaitu 75. Nilai tertinggi yang dapat diperoleh hanyalah 72 yang diraih oleh satu siwa. Nilai rata-rata dari tiap kelas paling tinggi yaitu 55. Jika dilihat dari perolehan nilai UTS mata pelajaran PDTO maka dapat dikatakan bahwa kompetensi yang diajarkan selama setengah semester belum mampu dicapai oleh siswa. Hal ini mengindikasikan tujuan pembelajaran yang diinginkan belum tercapai.

Kompetensi yang dimiliki siswa merupakan goal dalam program pembelajaran di SMK. Dalam program pembelajaran, kompetensi yang ingin dicapai dijabarkan dalam tujuan 
pembelajaran yang lebih bersifat praktis. Untuk mencapai sebuah tujuan maka diperlukan proses yang mendahuluinya. Nilai hasil belajar siswa merupakan salah satu indikator pencapaian kompetesi siswa yang merupakan product dari program pembelajaran itu sendiri. Sehingga dapat ditarik garis bahwa nilai merupakan indikator ketercapaian suatu kompetensi dan kualitas program pembelajaran yang terjadi disekolah.

Program pembelajaran Pekerjaan Dasar Teknik Otomotif merupakan pembelajaran dasar pekerjaan-pekerjaan dibidang otomotif dengan materi pokok pelajaran ini adalah peralatanperalatan yang digunakan dalam dibidang otomotif. Penguasaan kompetensi yang sifatnya dasar sangatlah penting sehingga akan membantu dalam pencapaian kompetensi pada tahap yang selanjutnya. Menilik kembali hasil UTS program pembelajaran PDTO di SMK Negeri 1 Sedayu yang belum memenuhi KKM, sangat berkaitan erat dengan program pembelajaran yang dilakukan. Maka dari pada itu, perlu dilakukan kajian yang lebih mendalam pada program pembelajaran Pekerjaan Dasar Teknik Otomotif kelas X pada program keahlian Teknik Kendaraan Ringan Otomotif di SMK Negeri 1 Sedayu.

Berdasarkan latar belakang masalah yang telah dikemukakan di atas, berikut beberapa masalah yang dapat diidentifikasi: (1) Kebijakan yang diambil lembaga pendidikan kurang tepat. (2) Fasilitas sekolah yang sudah rusak. (3) Sistem Penilaian yang tidak tepat. (4) Siswa tidak berkonsentrasi pada pembelajaran. (5) Kondisi fisik yang lelah dan motivasi rendah siswa. (6) Pemilihan metode dan media pembelajaran yang kurang tepat. (7) Program pembelajaran terutama komponen-komponennya tidak berjalan dengan baik.

Dalam penelitian ini, peneliti hanya akan memfokuskan pada evaluasi program pembelajaran Pekerjaan Dasar Teknik Otomotif Kelas X TKRO di SMK Negeri 1 Sedayu. Menurut Sudjana (2006: 21), mendefinisikan evaluasi program adalah kegiatan sistematis untuk mengumpulkan, mengolah, menganalisis dan menyajikan data sebagai masukan untuk pengambilan keputusan. Penelitian evaluasi ini bertujuan untuk menggambarkan program pembelajaran Pekerjaan Dasar Teknik Otomotif di SMK Negeri 1 Sedayu. Tujuan yang ingin dicapai dalam penelitian ini adalah: (1) Mengetahui kesesuaian tujuan pembelajaran dengan kurikulum dan penyampaian kompetensi dasar pembelajaran Pekerjaan Dasar Teknik Otomotif kelas X TKRO di SMK Negeri 1 Sedayu. (2) Mengetahui kualifikasi dan pengalaman guru mata pelajaran Pekerjaan Dasar Teknik Otomotif kelas X TKRO di SMK Negeri 1 Sedayu, motivasi siswa, dan ketersediaan sarana dan prasarana dalam proses pembelajaran. (3) Mengetahui pelaksanaan proses pembelajaran meliputi penggunaan media dan metode oleh guru, pemanfaatan sumber belajar, dan keterlaksanaan langkah pembelajaran pada mata pelajaran Pekerjaan Dasar Teknik Otomotif kelas X TKRO di SMK Negeri 1 Sedayu. (4) 
4 Agus Budiman, Zhafran Anas

Mengetahui pencapaian belajar siswa pada aspek afektif, kognitif, dan psikomotorik pada mata pelajaran Pekerjaan Dasar Teknik Otomotif kelas X TKRO di SMK Negeri 1 Sedayu.

\section{METODE}

Penelitian ini termasuk dalam penelitian deskriptif. Penelitian deskriptif untuk mengeksplorasi, menggambarkan, dengan tujuan untuk menjelaskan dan memprediksi suatu gejala berdasar data dari lapangan (Sukardi, 2014: 14). Penelitian ini diberi judul evaluasi program karena berfokus pada suatu kegiatan (program, proses, ataupun hasil kerja) dalam suatu unit (tempat, organisasi, ataupun lembaga) untuk menilai manfaat, sumbangan dan kelayakan dari kegiatan tersebut pada suatu unit (Sukmadinata, 2009: 16). Model evaluasi yang digunakan dalam penelitian ini adalah model CIPP. CIPP merupakan singkatan dari context, input, process, dan product.

Tempat penelitian yang dipilih adalah di SMK Negeri 1 Sedayu yang beralamat di Kemusuk, Agromulyo, Sedayu, Bantul, Daerah Istimewa Yogyakarta. Waktu pelaksanaan penelitian pada bulan Juli sampai dengan Agustus 2019.

Subyek penelitian merupakan sumber informasi. Subyek penelitian disesuaikan dengan permasalahan penelitian, sehingga subyek penelitiannya terdiri dari guru mata pelajaran Pekerjaan Dasar Teknik Otomotif berjumlah satu orang dan siswa kelas X TKROA, X TKROB, $\mathrm{X}$ TKROC dengan jumlah total 108 siswa.

Menurut Darmawan (2014: 159), teknik pengumpulan data merupakan cara-cara yang ditempuh dan alat-alat yang digunakan oleh peneliti dalam mengumpulkan data. Teknik yang digunakan meliputi: angket/kuesioner, pedoman wawancara, lembar pengamatan/observasi, dan studi dokumentasi. Angket dipakai untuk mengumpulkan data atau informasi yang bersumber dari siswa dengan fokus penelitian pada motivasi siswa mengikuti pelajaran, penggunaan media dan metode oleh guru, dan pemanfaatan sumber belajar pada mata pelajaran Pekerjaan Dasar Teknik Otomotif. Dokumentasi dipakai untuk mengumpulkan data atau informasi yang bersumber dari kurikulum, silabus, rencana pelaksanaan pembelajaran, dan lembar nilai siswa dengan fokus penelitian pada kesesuaian tujuan pembelajaran dengan kurikulum dan ketercapaian nilai siswa. Observasi dipakai untuk mengumpulkan data atau informasi yang bersumber dari ruang kelas, alat praktik, dan kegiatan belajar mengajar dengan fokus penelitian pada ketersediaan sarana dan prasarana di kelas, ketersediaan alat praktik PDTO, dan keterlaksanaan langkah pembelajaran. Dalam penelitian ini wawancara yang dilakukan termasuk dalam wawancara terstruktur dengan pedoman wawancara dan alat bantu berupa recorder. Wawancara dipakai untuk mengumpulkan data atau informasi yang bersumber 
dari guru dengan fokus penelitian pada kesesuaian tujuan pembelajaran dengan kurikulum, penyampaian kompetensi dasar pembelajaran, kualifikasi dan pengalaman guru. Selain itu juga akan ditanyakan berkaitan dengan motivasi siswa, sarana dan prasarana, media, metode, sumber belajar, dan langkah pembelajaran.

Teknik analisis data dilakukan berdasarkan jenis data yang diperoleh. Analisis data dilakukan secara deskriptif. Untuk data yang berbentuk kualitatif seperti data dari wawancara dan dokumentasi analisisnya secara deskriptif kualitatif. Sedangkan untuk angket dan observasi digunakan analisis secara deskriptif kuantitatif.

Analisa data kualitatif digunakan untuk menganalisa kesesuaian tujuan pembelajaran dengan kurikulum, penyampaian kompetensi dasar, kualifikasi guru, dan pengalaman guru. Menurut Sugiyono (2015: 338-345), langkah-langkah dalam menganalisis data kualitatif adalah sebagai berikut: (1) Reduksi Data (Data Reduction), yaitu merangkum, memilih hal-hal yang pokok, memfokuskan pada hal-hal yang penting, dicari tema dan polanya dan membuang yang tidak perlu. (2) Penyajian Data (Data Display), dengan menyajikan data akan memudahkan serta memahami apa yang terjadi dan memudahkan perencanaan kerja yang akan dilakukan selanjutnya, yang paling sering digunakan dalam menyajikan data pada penelitian kualitatif adalah dengan teks yang bersifat naratif. (3) Menarik Kesimpulan dan Verifikasi (Conclusion Drawing Verification), kesimpulan yang diharapkan adalah temuan baru yang sebelumnya belum pernah ada. Temuan tersebut dapat berupa deskripsi atau gambaran suatu obyek yang belum jelas sehingga akan menjadi jelas setelah diteliti.

Analisa data berkaitan dengan motivasi siswa, media pembelajaran, metode pembelajaran, dan sumber belajar dilakukan dengan menghitung persentase yang didapat pada setiap nomor butir pernyataan. Analisa data ketersediaan sarana dan prasarana dilakukan dengan cara menghitung persentase objek penelitian yaitu sarana dan prasarana yang ada di ruang kelas. Analisis keterlaksanaan langkah pembelajaran dilakukan dengan cara menghitung persentase antara pelaksanaan langkah pembelajaran oleh guru dengan langkah pembelajaran yang ada pada Permendikbud Nomor 34 Tahun 2018. Rumusnya sebagai berikut:

$\mathrm{P}=\frac{F}{N} \times 100 \%$

Keterangan:

$\mathrm{P}=$ Angka persentase

$\mathrm{F}=$ Frekuensi data yang sedang dicari presentasenya

$\mathrm{N}=$ Jumlah data

(Sudijono, 2007: 43) 
Nilai persentase tersebut kemudian ditentukan kategorinya berdasarkan tabel berikut:

Tabel 1. Kategori Interval Nilai Persentase.

\begin{tabular}{ll}
\hline \multicolumn{1}{c}{ Interval } & \multicolumn{1}{c}{ Keterangan } \\
\hline $81 \%-100 \%$ & Sangat Baik \\
$61 \%-80 \%$ & Baik \\
$41 \%-60 \%$ & Cukup \\
$21 \%-40 \%$ & Kurang \\
$0 \%-20 \%$ & Sangat Kurang \\
\hline
\end{tabular}

(Arikunto, 1988: 214)

Data yang dianalisis secara kuantitatif adalah data dalam bentuk angket. Data kuantitatif dianalisis dengan menggunakan analisis statistik yang terdiri dari Mean (M), standar deviasi (SD), median (Mdn) dan modus (Mo). Pemberian skoring dibuat dengan skala likert dengan skor 1 sampai 4. Adapun cara yang digunakan adalah dengan mengidentifikasi kecenderungan skor rata-rata data. Menurut Mardapi (2008: 123), pengelompokkan tersebut menggunakan rumus sebagai berikut:

Tabel 2. Kriteria Penilaian.

\begin{tabular}{ll}
\hline Rentang Skor & Kategori \\
\hline $\mathrm{X} \geq \mathrm{Mi}+\mathrm{Sdi}$ & Sangat Baik \\
$\mathrm{Mi}+$ 1.Sdi $>\mathrm{X} \geq \mathrm{Mi}$ & Baik \\
$\mathrm{Mi}>\mathrm{X} \geq \mathrm{Mi}-1$.Sdi & Cukup Baik \\
$\mathrm{X}<\mathrm{Mi}-1 . \mathrm{Sdi}$ & Kurang Baik \\
\hline
\end{tabular}

Keterangan:

$\mathrm{Mi}=$ Rerata skor dapat dicapai instrumen, rumus: 1/2 (skor tertinggi ideal + skor terendah ideal)

Sdi= Simpangan baku yang dapat dicapai instrumen, rumus: 1/6 (skor tertinggi ideal - skor terendah ideal)

$\mathrm{X}=$ Skor yang dicapai instrumen

\section{HASIL DAN PEMBAHASAN}

\section{Kesesuaian Tujuan Pembelajaran Dengan Kurikulum}

Dalam Rencana Pelaksanaan Pembelajaran memuat banyak unsur diantaranya tujuan dan materi. Tujuan dan materi pembelajaran yang dibuat oleh guru mata pelajaran Pekerjaan Dasar Teknik Otomotif sudah sesuai dengan kurikulum 2013 edisi revisi 2017. Seperti halnya yang diungkapkan oleh guru mata pelajaran Pekerjaan Dasar Teknik Otomotif, bahwa "Sudah sesuai. Kalau yang sekarang menekankan pada pendidikan karakter" dan "Kami berusaha (menyusun 
materi pembelajaran) mengacu ke kurikulum". Selaras dengan itu Wakil Kepala Sekolah Bidang Kurikulum mengungkapkan bahwa "Kemudian acuan kurikulumnya disini kita cek apakah formatnya sudah sama biar satu sekolah ini tidak terlalu banyak variasinya jangan sampai kreasinya terlalu banyak sehingga, format bakunya ada. Tapikan setiap guru punya hak untuk mengkreasikan apa yang dibuat tapi format baku itu yang saya periksa yang penting unsur yang harus minimal ada. Kalau belum ada atau belum sesuai urutannya tidak sama, nah itu yang kita sampaikan ke gurunya untuk diperbaiki, untuk kemudian disahkan oleh Bapak Kepala Sekolah. Untuk kesesuaiannya sendiri telah sesuai dengan format yang disepakati dan secara jumlah sudah semua dan juga secara kualitas sekiranya sudah".

Tabel 3. Dokumentasi Perencanaan Pembelajaran Program Pembelajaran PDTO.

\begin{tabular}{|c|c|c|c|c|}
\hline No. & Dokumen & $\begin{array}{l}\text { Ada } \\
(\mathrm{V})\end{array}$ & $\begin{array}{l}\text { Tidak } \\
\text { (V) }\end{array}$ & Keterangan \\
\hline 1. & Kurikulum 2013 & V & & $\begin{array}{l}\text { Peraturan Direktur Jendral Pendidikan } \\
\text { Dasar Dan Menengah Kementrian } \\
\text { Pendidikan Dan Kebudayaan No } \\
\text { 464/D.D5/KR/2018 }\end{array}$ \\
\hline 2. & Silabus & $\mathrm{V}$ & & \\
\hline 3. & $\begin{array}{l}\text { Rencana } \\
\text { Pelaksanaan } \\
\text { Pembelajaran } \\
\text { (RPP) }\end{array}$ & V & & $\begin{array}{l}\text { RPP untuk kompentensi pengetahuan ada } \\
\text { tetapi untuk kompetensi keterampilan } \\
\text { tidak ada. }\end{array}$ \\
\hline
\end{tabular}

\section{Penyampaian Kompetensi Dasar Pembelajaran}

Penyampaian kompetensi dasar belum maksimal dilakukan. Seperti diungkapakan oleh guru mata pelajaran Pekerjaan Dasar Teknik Otomotif, menyebutkan bahwa "Kami berusaha menyampaikan sesuai kurikulum tetapi melihat situasi, waktu, dan kondisi. Jadi pencapaian kurikulum belum tentu 100\%, tetapi tetap berusaha maksimal. 85-95\% tersampaikan ke siswa". Banyak faktor yang menyebabkan hal tersebut terjadi, diantaranya terkendala waktu dan siswa tidak mengikuti pembelajaran. Seperti diungkapan oleh guru mata pelajaran Pekerjaan Dasar Teknik Otomotif, bahwa "Faktor waktu, jadi misalnya situasi sudah direncanakan tapi karena kondisi situasional, misalnya terjadi rapat kegiatan sekolah dan sebagainya dan itupun tidak bisa ditinggalkan sehingga pencapaian kurikulumnya pun kadang kurang waktu" dan "Mungkin karena siswa itu tidak hadir, mungkin karena sakit dan sebagainya". 
8 Agus Budiman, Zhafran Anas

\section{Kualifikasi Guru}

Guru pengampu mata pelajaran Pekerjaan Dasar Teknik Otomotif berjumlah 1 orang dan mengajar 3 kelas, latar belakang pendidikan beliau yaitu SD dan SMP di Pekalongan, STM 1 Semarang, D3 Otomotif VEDC Malang lulus tahun 1991, dan S1 Universitas Sarjanawiyata Tamansiswa (UST) masuk tahun 2001 lulus tahun 2003. Beliau sudah mengajar selama 27 tahun mulai 1 Maret 1992 di SMK Negeri 1 Sedayu dan pada tahun 2009 beliau sudah sertifikasi pendidik.

\section{Pengalaman Guru}

Pelatihan-pelatihan teknik yang pernah diikuti yaitu diklat rem di Suzuki Jakarta selama 1 minggu pada tahun 2003, diklat EFI di VEDC Malang selama 2 minggu pada tahun 2007, diklat control unit di VEDC Malang selama 2 minggu pada tahun 2008, diklat manajemen bengkel selama 1 minggu pada tahun 2019 penyelanggara UNY, diklat kepala bengkel di SMK 1 Sedayu selama 3 bulan pada 2010 penyelanggara VEDC Malang. Untuk pelatihan mengajar yang pernah diikuti yaitu diklat kurikulum 2013 selama 10 hari pada tahun 2015 yang diselenggarakan oleh VEDC Malang dan diklat kesiswaan (kompetensi bidang kesiswaan) yang diselanggarakan oleh DIKPORA DIY bekerjasama dengan SMK 3 Tegal selama 1 bulan di SMK 3 Tegal pada tahun 2005.

\section{Motivasi Siswa Mengikuti Program Pembelajaran PDTO}

Hasil data dari pengisian angket dengan jumlah pernyataan 21 butir diperolah mean 60,7037, median 60,00, modus 58,00, dan standar deviasi 8,17022. Pengelompokan motivasi siswa mengikuti mata pelajaran Pekerjaan Dasar Teknik Otomotif dibagi menjadi 4 kategori yaitu sangat baik, baik, cukup baik, dan kurang baik.

Tabel 4. Distribusi Frekuensi Motivasi Siswa Mengikuti Mata Pelajaran PDTO.

\begin{tabular}{llcc}
\hline \multicolumn{1}{c}{ Kelas Interval } & Kategori & Frekuensi & $\begin{array}{c}\text { Persentase } \\
(\%)\end{array}$ \\
\hline $\mathrm{X} \geq 68,874$ & Sangat Baik & 18 & 16,667 \\
$68,874>\mathrm{X} \geq 60,704$ & Baik & 29 & 26,852 \\
$60,704>\mathrm{X} \geq 52,533$ & Cukup Baik & 50 & 46,296 \\
$\mathrm{X}<52,533$ & Kurang baik & 11 & 10,185 \\
Jumlah & & 108 & 100 \\
\hline
\end{tabular}




\section{Ketersediaan Sarana Dan Prasarana Di Ruang Kelas}

Berdasarkan hasil observasi di tiga ruang kelas yang berbeda tersebut diambil satu data yang menjadi hasil penelitian ketersediaan sarana dan prasarana dengan persentase yaitu 63,634\% atau masuk dalam kategori baik. Hal ini dilakukan karena sarana dan prasarana akan terus berubah setiap waktunya, sehingga yang dijadikan acuan hasil penelitian adalah persentase ketersediaan paling rendah dari hasil observasi ruang kelas.

Berdasarkan wawancara dengan guru mata pelajaran Pekerjaan Dasar Teknik Otomotif dan Wakil Kepala Sekolah bidang sarana dan prasarana menyampaikan bahwa sarana dan prasarana yang ada di ruang kelas sudah cukup dan terpenuhi. Wakil Kepala Sekolah juga menambahkan bahwa kelengkapan ruang kelas seperti papan tulis dan kelengkapannya, jadwal pelajaran, jadwal piket, foto presiden dan wakil presiden, pancasila, meja kursi siswa, dan meja kursi guru.

\section{Ketersediaan Alat Praktik Di Bengkel TKRO}

Berdasarkan data observasi ketersediaan alat praktik di bengkel TKRO SMK Negeri 1 Sedayu dapat diketahui bahwa alat praktik PDTO yang tersedia di SMK Negeri 1 Sedayu secara umum tersedia, walaupun beberapa alat tidak tersedia dan sebagian kecil alat praktik ada yang rusak. Alat praktik yang tersedia berjumlah 82 macam dari 95 macam, persentase ketersediaan alat praktik PDTO adalah 86,318\% atau dalam kategori sangat baik.

Berdasarkan wawancara dengan Wakil Kepala Sekolah Bidang Sarana dan Prasarana dan guru mata pelajaran Pekerjaan Dasar Teknik Otomotif, menyebutkan bahwa ketersediaan alat praktik penunjang program pembalajaran Pekerjaan Dasar Teknik Otomotif di SMK Negeri 1 Sedayu sudah mencukupi untuk menjalankan program pembelajaran meskipun masih sebatas standar pelayanan minimal. Kebersihan tempat praktik atau bengkel selalu dijaga oleh setiap komponen dalam sekolah.

\section{Penggunaan Media Pembelajaran}

Hasil data dari pengisian angket dengan responden siswa kelas X TKRO tentang media pembelajaran diperolah mean 34,3519, median 34,00, modus 34,00, dan standar deviasi 5,32902 .

Berdasarkan hasil wawancara dengan guru mata pelajaran Pekerjaan Dasar Teknik Otomotif, media pembelajaran diantaranya peralatan atau bahan yang ada di bengkel. Jika di ruang kelas contohnya proyektor dan kelengkapannya termasuk laptop dan sebagainya. Pemanfaatan media juga diikuti dengan memcontohkan penggunaan alatnya. 
10 Agus Budiman, Zhafran Anas

Tabel 1. Distribusi Frekuensi Penggunaan Media Pembelajaran Oleh Guru Mata Pelajaran PDTO (Responden Siswa Kelas X TKRO).

\begin{tabular}{llcc}
\hline \multicolumn{1}{c}{ Kelas Interval } & Kategori & Frekuensi & Persentase (\%) \\
\hline $\mathrm{X} \geq 39,682$ & Sangat Baik & 19 & 17,593 \\
$39,682>\mathrm{X} \geq 34,353$ & Baik & 33 & 30,556 \\
$34,353>\mathrm{X} \geq 29,024$ & Cukup Baik & 38 & 35,185 \\
$\mathrm{X}<29,024$ & Kurang baik & 18 & 16,667 \\
Jumlah & & 108 & 100 \\
\hline
\end{tabular}

\section{Penggunaan Metode Pembelajaran}

Hasil data dari pengisian angket dengan responden siswa kelas X TKRO tentang metode pembelajaran diperolah mean 31,8056, median 31,00, modus 30,00, dan standar deviasi 4,43954 .

Tabel 2. Distribusi Frekuensi Penggunaan Metode Pembelajaran Oleh Guru Mata Pelajaran PDTO (Responden Siswa Kelas X TKRO).

\begin{tabular}{llcc}
\hline Kelas Interval & Kategori & Frekuensi & Persentase (\%) \\
\hline $\mathrm{X} \geq 36,245$ & Sangat Baik & 15 & 13,889 \\
$36,245>\mathrm{X} \geq$ & Baik & 37 & 34,259 \\
31,806 & & \\
$31,806>\mathrm{X} \geq$ & Cukup Baik & 41 & 37,963 \\
27,366 & & \\
$\mathrm{X}<27,366$ & Kurang baik & 15 & 13,889 \\
Jumlah & & 108 & 100 \\
\hline
\end{tabular}

\section{Pemanfaatan Sumber Belajar}

Hasil data dari pengisian angket dengan responden siswa kelas X TKRO tentang sumber belajar diperolah mean 34,9630, median 35,00, modus 35,00, dan standar deviasi 7,81076.

Berdasarkan wawancara dengan guru mata pelajaran Pekerjaan Dasar Teknik Otomotif, sumber belajar yang biasa dimanfaatkan adalah buku dari pesputakaan sekolah dan bengkel TKRO. Selain internet juga dimanfaatkan sebagai sumber belajar dalam mendukung program pembelajaran. 
Tabel 3. Distribusi Frekuensi Pemanfaatan Sumber Belajar Dalam Program Pembelajaran PDTO (Responden Siswa Kelas X TKRO).

\begin{tabular}{llcc}
\hline \multicolumn{1}{c}{ Kelas Interval } & \multicolumn{1}{c}{ Kategori } & Frekuensi & Persentase (\%) \\
\hline$X \geq 42,774$ & Sangat Baik & 17 & 15,741 \\
$42,774>X \geq 34,963$ & Baik & 40 & 37,037 \\
$34,963>X \geq 27,152$ & Cukup Baik & 36 & 33,333 \\
$X<27,152$ & Kurang baik & 15 & 13,889 \\
Jumlah & & 108 & 100 \\
\hline
\end{tabular}

\section{Keterlaksanaan Langkah Pembelajaran}

Langkah pembelajaran yang terlaksana pada program pembelajaran Pekerjaan Dasar Teknik Otomotif sudah terlaksana semua. Jika berdasarkan Permendikbud Nomor 34 Tahun 2018 dan Permendikbud Nomor 81A Tahun 2013, didapatkan 17 langkah pembelajaran yang terlaksana $100 \%$ atau dalam kategori sangat baik.

Bedasarkan wawancara dengan guru mata pelajaran Pekerjaan Dasar Teknik Otomotif, langkah pembelajaran yang sudah direncanakan dalam Rencana Pelaksanaan Pembelajaran bisa saja berubah tergantung situsi dan kondisi sehingga bersifat fleksibel.

\section{Pencapaian Hasil Belajar Siswa}

Salah satu indikator program pembelajaran Pekerjaan Dasar Teknik Otomotif dikatakan berhasil apabila pencapaian prestasi belajar peserta didik telah memenuhi kriteria kelulusan minimum (KKM) yang telah ditetapkan. KKM mata pelajaran Pekerjaan Dasar Teknik Otomotif di SMK Negeri 1 Sedayu adalah 75. Hasil evaluasi produk yang sudah dilakukan oleh guru mata pelajaran PDTO sebanyak dua kali menunjukkan rerata nilai tugas peserta didik sebesar 56,528 untuk tugas 1 dan 63,796 untuk tugas 2. Jika dilihat dari tingkat ketuntasannya, maka hasil evaluasi produk menunjukkan pada tugas 1 terdapat 45 peserta didik tuntas dengan persentase $41,667 \%$ dan 63 peserta didik tidak tuntas. Sedangkan pada tugas 2 terdapat 59 peserta didik tuntas dengan persentase 54,630\% dan 49 peserta didik tidak tuntas. 
12 Agus Budiman, Zhafran Anas

\section{Pembahasan Hasil Penelitian}

\section{Kesesuaian tujuan pembelajaran dengan kurikulum}

Berdasarkan hasil penelitian yang didapat dari wawancara guru pengampu mata pelajaran Pekerjaan Dasar Teknik Otomotif dan Wakil Kepala Sekolah Bidang Kurikulum, Rencana Pelaksanaan Pembelajaran (RPP) yang memuat tujuan pembelajaran dan materi pembelajaran telah sesuai dengan Kurikulum 2013 Edisi Revisi 2017 yang dipakai di SMK Negeri 1 Sedayu. Tujuan pembelajaran merupakan target yang ingin dicapai dalam kegiatan pembelajaran sekaligus landasan dalam menentukan strategi, materi, media, dan evaluasi pembelajaran (Hamruni, 2011: 12). Pentingnya kesesuaian tujuan pembelajaran dengan kurikulum akan menentukan proses pembeajaran. Perencanaan pembelajaran harus dirancang dan diatur agar setiap tindakan kegiatan berjalan dengan efektif.

Dalam mengatur kelengkapan perangkat mengajar guru di SMK Negeri 1 Sedayu, selalu dikontrol dalam penyusunannya. Guru sebagai menyusun perangkat pembelajaran harus berpatokan pada peraturan yang ditetapkan olah sekolah. Di SMK Negeri 1 Sedayu, kompetensi inti dan kompetensi dasar yang dijadikan acuana adalah Perdirjen No. 464 Tahun 2018. Rencana Pelaksanaan Pembelajaran mata pelajaran Pekerjaan Dasar Teknik Otomotif dikatakan sudah sesuai dengan kurikulum yang dipakai di SMK Negeri 1 Sedayu, hal tersebut selaras dengan pernyataan Wakil Kepala Sekolah Bidang Kurikulum, beliau menyampaikan bahwa "untuk kesesuaiannya sendiri telah sesuai dengan format yang disepakati dan secara jumlah sudah semua dan juga secara kualitas sekiranya sudah”.

Berdasarkan hasil penelitian dari kesesuaian tujuan pembelajaran dengan kurikulum pada program pembelajaran PDTO di SMK Negeri 1 Sedayu, menunjukkan bahwa RPP yang didalamnya memuat tujuan pembelajaran sudah dibuat sesuai dengan Kurikulum 2013 Edisi Revisi 2017 yang dipakai di SMK Negeri 1 Sedayu. Dapat diketahui juga bahwa penelitian ini mendukung penelitian dari Mawarni (2017) dengan hasil bahwa materi pembelajaran pengetahuan bahan tekstil yang diajarkan dan tujuan pembelajaran telah sesuai dengan kurikulum 2013 SMK. Dikatakan mendukung karena lingkup penelitiannya sama yaitu SMK meskipun pada program yang berbeda.

\section{Penyampaian kompetensi dasar pembelajaran}

Dari hasil wawancara dengan guru mata pelajaran Pekerjaan Dasar Teknik Otomotif, pelaksanaan penyampaian kompetensi dasar belum semua kompetensi dasar dapat tersampaikan dengan maksimal. Kompetensi dasar yang tidak tersampaikan dengan maksimal dikarenakan terkendala faktor waktu. Untuk mengatasi agar setiap kompetensi dasar tetap tersampaikan guru mempercepat penyampaian kompetensi dasar sehingga semua kompetensi 
dapat tersampaikan semua. Semua kompetensi dasar tetap diajarkan tetapi materi yang disampaikan tidak mendetail, hanya disampaikan dasar-dasarnya saja. Untuk mengatasi hal seperti itu guru pengampu memberikan tugas mandiri kepada siswa dengan harapan siswa belajar sendiri untuk mengembangkan dasar-dasar yang telah diberikan oleh guru saat pembelajaran di kelas.

Hasil penelitian tentang penyampaian materi pembelajaran senada dengan penelitian Nurmalita (2014: 85) yang menyatakan bahwa penyampaian materi tidak semuanya dapat disampaikan secara keseluruhan mengingat materi yang diajarkan sangat banyak namun waktu tidak memenuhi sehingga ada pembagian waktu dalam menerangkan materi. Senada dengan itu hasil penelitian Laksono (2017: 77) juga menyatakan bahwa tidak semua kompetensi dasar tersampaikan dan kebijakan guru dalam mengisi materi yang tidak tersampaikan tersebut dengan materi yang diminati peserta didik. Selaras dengan itu, hasil penerlitian Subiyantoro (2018: 100) menyatakan bahwa penyampaian materi tidak semuanya dapat disampaikan secara keseluruhan mengingat materi yang diajarkan sangat banyak namun waktu yang tidak memenuhi sehingga ada beberapa materi yang tidak dibahas secara lebih mendalam. Penyampaian kompetensi dasar pembelajaran secara realistis dilapangan memang berbeda jika dibandingkan dengan perencanaan yang sudah disusun oleh guru, dalam praktiknya banyak halhal penghambat yang mengakibatkan kompetensi dasar tidak tersampikan ke siswa, misalnya kesibukan guru dan kegiatan-kegiatan yang dilaksanakan sekolah.

\section{Kualifikasi Guru}

Berdasarkan hasil penelitian tentang kualifikasi dan pengalaman guru diketahui guru pengampu mata pelajaran Pekerjaan Dasar Teknik Otomotif berjumlah 1 orang yang memiliki latar belakang S1 Jurusan Pendidikan Teknik Mesin. Guru mata pelajaran Pekerjaan Dasar Teknik Otomotif sudah memiliki sertifikasi pendidik pada sejak tahun 2009.

Hasil penelitian berkenaan dengan kualifikasi guru program pembelajaran PDTO senada dengan hasil penelitian Subiyantoro (2018: 99), Laksono (2017: 77), dan Nurmalita (2014: 85) yang menyatakan bahwa latar belakang pendidikan guru adalah Sarjana Pendidikan (S1). Dalam Permendikbud Nomor 34 tahun 2018 pada Lampiran V Bab III tentang Standar Kualifikasi Akademik Guru Dan Instruktur Kejuruan, telah diatur bahwa latar belakang pendidikan guru untuk jenjang SMK/MAK minimal adalah sarjana (S1) atau sarjana terapan (D-IV). 
14 Agus Budiman, Zhafran Anas

\section{Pengalaman Guru}

Pengalaman mengajar guru mata pelajaran Pekerjaan Dasar Teknik Otomotif adalah 27 tahun. Selama mengajar, mata pelajaran yang pernah diampu adalah Dasar Teknik Otomotif, Kerja Bangku, Listrik, Chassis/Transmisi, Mesin, Gambar Teknik, Pekerjaan Dasar Teknik Otomotif, dan Teknologi Dasar Otomotif. Mata pelajaran Pekerjaan Dasar Teknik Otomotif sudah diampu selama 5 tahun terakhir.

Selain pengalaman mengajar, pelatihan juga penting untuk menambah kemampuan guru dalam menjalankan tugasnya. Pelatihan-pelatihan teknik yang pernah diikuti yaitu diklat rem di Suzuki Jakarta selama 1 minggu pada tahun 2003, diklat EFI di VEDC Malang selama 2 minggu pada tahun 2007, diklat control unit di VEDC Malang selama 2 minggu pada tahun 2008, diklat manajemen bengkel selama 1 minggu pada tahun 2019 penyelanggara UNY, diklat kepala bengkel di SMK 1 Sedayu selama 3 bulan pada 2010 penyelanggara VEDC Malang. Untuk pelatihan mengajar yang pernah diikuti yaitu diklat kurikulum 2013 selama 10 hari pada tahun 2015 yang diselenggarakan oleh VEDC Malang dan diklat kesiswaan (kompetensi bidang kesiswaan) yang diselanggarakan oleh DIKPORA DIY bekerjasama dengan SMK 3 Tegal selama 1 bulan di SMK 3 Tegal pada tahun 2005.

\section{Motivasi siswa mengikuti program pembelajaran Pekerjaan Dasar Teknik Otomotif}

Berdasarkan hasil penelitian, dapat diketahui bahwa rerata motivasi siswa mengikuti mata pelajaran Pekerjaan Dasar Teknik Otomotif dikategorikan baik dengan persentase 72,266\%. Kecenderungan motivasi siswa dalam mengikuti program pembelajaran PDTO dikategorikan cukup baik dengan persentase 46,296\%. Motivasi pada diri seseorang mampu mendorong dirinya untuk berusaha lebih giat sehingga memperoleh sukses lebih besar (Karwono \& Mularsih, 2017: 49). Siswa yang memiliki motivasi yang tinggi memiliki peluang untuk lebih berprestasi dari pada siswa yang memiliki motivasi yang rendah, karena motivasi yang dimiliki siswa akan akan menimbulkan siswa aktif menikuti kegiatan pembelajaran. Hasil penelitian Marwanto dan Djatmiko (2014) mengungkapkan bahwa didalam pembelajaran hambatan yang dialami dosen antara salah satunya adalah motivasi mahasiswa yang kurang. Dari hasil penelitian tersebut dapat ditarik garis bahwa motivasi peserta didik dapat berpengaruh dalam suatu program pembelajaran baik itu bersifat positif mendukung pembelajaran ataupun negatif menjadi penghambat pembelajaran.

\section{Ketersediaan sarana dan prasarana di ruang kelas}

Berdasarkan hasil penelitian, dapat diketahui bahwa ketersediaan sarana dan prasarana di ruang kelas TKRO SMK Negeri 1 Sedayu dikategorikan baik dengan persentase 63,634\%. 
Sarana dan prasarana yang tersedia dikelas antara lain meja, kursi, papan tulis, alat kebersihan, kotak kontak, screen (layar LCD proyektor), lampu, dan kipas angin. Masalah yang muncul pada sarana dan prasarana di ruang kelas adalah lampu yang hilang diambil oleh siswa. Untuk mengatasi hal-hal yang tidak diinginkan, maka pihak sekolah pada mulai tahun ajaran 2019/2020 memasang kamera CCTV sebagai bentuk pengawasan lingkungan sekolah. Sarana dan prasarana yang tidak diletakkan di ruang kelas seperti LCD proyektor dan alat tulis. LCD proyektor tidak dipasang pada ruang kelas untuk mencegah agar tidak rusak. Kebersihan pada ruang kelas kurang terjaga dengan baik sehingga terdapat kotor terutama pada bagian lantai.

Menurut Lampiran VI Permendikbud Nomor 34 Tahun 2018, sarana dan prasarana di ruang kelas yang digunakan mata pelajaran Pekerjaan Dasar Teknik Otomotif terdapat fasilitas yang belum ada misalnya lambing negara, gambar presiden dan wakil presiden. Jika dikaitkan dengan proses pembelajaran yang dilakukan fasilitas tersebut tidak ada pengaruhnya langsung pada program pembelajaran pkerjaan dasar teknik otomotif, tetapi dalam pendidikan karakter akan sangat penting agar menanampkan rasa cinta terhadap negara. Menurut Jabar (2016: 117) sarana dan prasarana adalah segala sesuatu yang berujud benda atau yang dibendakan yang secara langsung dan tidak langsung dapat memudahkan pelaksanaan kegiatan dalam mencapai suatu tujuan. Pemenuhan sarana dan prasarana agar sesuai dengan standar yang telah ditetapkan harus dilakukan sehingga tujuan pembelajaran dapat tercapai.

\section{Ketersediaan alat praktik program pembelajaran PDTO di bengkel TKRO}

Berdasarkan hasil penelitian, dapat diketahui bahwa ketersediaan alat praktik PDTO di bengkel TKRO SMK Negeri 1 Sedayu dikategorikan sangat baik dengan persentase $86,318 \%$. Terdapat 82 macam dari 95 macam alat praktik yang dimiliki bengkel TKRO SMK Negeri 1 Sedayu. Alat praktik yang tidak tersedia di bengkel TKRO meliputi tube cutter, air chisel, abrasive cut off saw, penekan piston rem cakram (disk brake piston compressor), traker ball joint (ball joint separator), forklift, penyetal lampu kepala (head lamps adjustment), depth gauge, telescoping gauge, compound gauge, manifold pressure gauge, arbour press.

Dari hasil wawancara dengan guru mata pelajaran Pekerjaan Dasar Teknik Otomotif dan Wakil Kepala Sekolah bidang sarana dan prasarana, sarana dan prasarana praktik telah mencukupi meskipun sebatas standar pelayanan minimal dan masih akan ada proses pengadaan sehingga dapat terpenuhi secara maksimal. Kebersihan sarana dan prasarana praktik kurang terjaga terutama lantai pada bengkel TKRO dan engine stand yang tidak digunakan juga berdebu. Alat praktik dalam kondisi baik dan bersih tetapi ada yang rusak. Kondisi rusak diakibatkan olah penggunaan saat praktik. 
16 Agus Budiman, Zhafran Anas

Menurut Jabar (2016: 131), sarana dan prasarana harus dipergunakan secara efektif dan efisien. Efektif berarti pemakaian perlengkapan pendidikan di sekolah harus ditunjukan sematamata dalam rangka memperlancar pencapaian tujuan pendidikan baik secara langsung maupun tidak langsung. Efisien berarti pemakaian semua perlengkapan pendidikan di sekolah secara hemat dan dengan hati-hati. Penggunaan alat praktik secara maksimal dalam setiap penyampaian kompetensi akan membuat membuat pengalaman belajar siswa menjadi berkembang. Pada pembelajaran Pekerjaan Dasar Teknik Otomotif pengenalan dan penggunaan alat begitu penting karena sebagai dasar untuk melakukan pekerjaan otomotif. Pencontohan dan pengawasan penggunaan alat praktik oleh guru akan mendukung siswa dalam mencapai tujuan pembelajaran dan menjaga keselamatan kerja baik dari alat, bahan ataupun individunya.

\section{Penggunaan media pembelajaran oleh guru program pembelajaran PDTO}

Berdasarkan hasil penelitian, dapat diketahui bahwa penggunaan media pembelajaran oleh guru mata pelajaran Pekerjaan Dasar Teknik Otomotif dapat dikategorikan baik dengan persentase $71,566 \%$. Kecenderungan penggunaan media pembelajaran oleh guru masih dalam kategori cukup baik dengan persentase 35,185\%. Media pembelajaran akan membantu guru dalam memperjelas penyampaian materi kepada siswa. Media pembelajaran yang sering dipakai oleh guru adalah LCD proyektor, laptop dan alat praktik.

Hasil penelitian penggunaan media pembelajaran, selaras dengan hasil penelitian Nurmalita (2014: 86) yang menyatakan media yang digunakan guru selama proses belajar mengajar berlangsung untuk mata pelajaran Mengolah Makanan Kontinental masuk dalam kategori cukup baik. Guru menggunakan media power point, gambar, video dan bahan asli. Alat praktik atau benda asli digunakan agar siswa paham cara penggunaannya. Hal tersebut selaras dengan pernyataan Hamalik (2013: 81), pengajaran akan berjalan lebih efektif, apabila guru dan siswa mempergunakan alat/media yang memadai. Penggunaan media pembelajaran yang bervariasi akan berdampak pada pengalaman belajar siswa dengan harapan siswa akan selalu ingat dan mampu mengaplikasikan ilmunya.

\section{Penggunaan metode pembelajaran oleh guru program pembelajaran PDTO}

Berdasarkan hasil penelitian, dapat diketahui bahwa penggunaan metode pembelajaran oleh guru mata pelajaran Pekerjaan Dasar Teknik Otomotif dapat dikategorikan baik dengan persentase $72,285 \%$. Kecenderungan penggunaan metode pembelajaran oleh guru mata pelajaran dikategorikan cukup baik dengan persentase 37,963\%. Metode pembelajaran yang sering guru pakai adalah ceramah, diskusi dan demonstrasi. 
Hasil penelitian penggunaan metode pembelajaran, selaras dengan hasil penelitian Nurmalita (2014: 86) yang menyatakan metode yang digunakan guru selama proses belajar mengajar berlangsung untuk mata pelajaran Mengolah Makanan Kontinental masuk dalam kategori cukup baik. Sedangkan metode pembelajaran menggunakan metode ceramah, diskusi, survey dan demonstrasi. Terkait metode pembelajaran yang dilakukan pada program pembelajaran, kegiatan belajar akan seimbang dan sesuai dengan siswa, apabila metode yang digunakan serasi dengan tujuan yang ingin dicapai (Hamalik, 2013: 80-81). Penggunaan metode pembelaajaran harus fleksibel dan bervariasi sehingga siswa dapat memahami materi yang disampaikan.

\section{Pemanfaatan sumber belajar dalam program pembelajaran PDTO oleh guru dan siswa}

Berdasarkan hasil penelitian, dapat diketahui bahwa pemanfaatan sumber belajar pada mata pelajaran Pekerjaan Dasar Teknik Otomotif dapat dikategorikan baik dengan persentase $62,434 \%$. Kecenderungan pemanfaatan sumber belajar dalam mata pelajaran dikategorikan cukup baik dengan persentase 37,963\%. Sumber belajar yang dipakai dalam program pembelajaran Pekerjaan Dasar Teknik Otomotif adalah buku dan internet. Menurut Khuluqo (2017: 61), pemanfaatan sumber-sumber belajar tergantung pada kreativitas pendidik, waktu, biaya serta kebiijakan-kebijakan lainnya. Dari pendapat tersebut, seorang pendidik yang memanfaatkan berbagai sumber belajar dapat membantu memperbaiki proses pembelajaran.

\section{Keterlaksanaan langkah pembelajaran oleh guru program pembelajaran PDTO}

Berdasarkan hasil penelitian, dapat diketahui bahwa keterlaksanaan langkah pembelajaran oleh guru mata pelajaran Pekerjaan Dasar Teknik Otomotif dapat dikategorikan sangat baik dengan persentase $100 \%$. Dalam program pembelajaran yang dilakukan guru langkah pembelajaran yang dilakukan bersifat fleksibel atau tidak berurutan. Hal tersebut terjadi karena situasi yang terjadi dikelas dapat berubah, sehingga perlu dibuat agar suasana kelas kondusif. Menurut Khuluqo (2017: 60) pendidik harus mampu membangun susana kondusif sehingga peserta didik mampu belajar mandiri.

\section{Pencapaian hasil belajar siswa pada program pembelajaran PDTO}

Berdasarkan hasil penelitian pada nilai siswa dalam mata pelajaran PDTO, didapatkan nilai rata-rata siswa kelas X TKRO pada tugas 1 dan tugas 2 belum mencapai KKM. Pada tugas 1 rerata nilainya sebesar 56,528 dan tugas 2 rerata nilainya 63,796. Jumlah siswa yang sudah memenuhi nilai KKM pada tugas 1 adalah 45 siswa dengan persentase $41,667 \%$ dan pada tugas 
18 Agus Budiman, Zhafran Anas

2 adalah 59 siswa dengan persentase 54,630\%. Menurut Slameto (2003: 54), faktor-faktor yang mempengaruhi prestasi belajar dapt digolongkan menjadi dua, yaitu faktor internal dan faktor eksternal, termasuk didalamnya adalah kesiapan peserta didik untuk mengikuti pelajaran. Banyak faktor yang menyebabkan prestasi peserta didik kurang baik seperti peserta didik masih dalam masa peralihan dari SMP ke SMK. Seperti yang diungkapkan guru program pembelajaran PDTO bahwa "kelas 1 pola piker masih seperti anak SMP dan perlu adaptasi dengan lingkungan SMK”. Selain itu faktor dari diri siswa salah satunya faktor fisik berupa kelelahan juga bisa mempengaruhi prestasi belejar siswa. Seperti halnya diungkapkan guru PDTO bahwa "karena faktor kecapekan, faktor kejenuhan karena sudah waktunya jadi siswa seharian belajar". Untuk faktor kelelahan ini guru PDTO tidak bisa berbuat banyak karena tidak bisa memaksakan agar siswa terus belajar, sehingga guru hanya bisa memotivasi siswa. Seperti yang diungkapkan guru PDTO bahwa "karena faktor kelelahan kita juga manusia jadi kita harus coro wong jowo "tepo seliro" jadi tidak memberi beban yang berat dan diberi motivasi gambaran misalnya kalau kerja bukan hanya sampai jam 3 tapi jam 5 jam 6 kamu itu lebih beruntung misalnya kalau dibandingkan dengan daerah yang terpencil sulit internet sulit listrik kamu lebih bersyukur".

\section{SIMPULAN}

Program pembelajaran mata pelajaran Pekerjaan Dasar Teknik Otomotif kelas X TKRO di SMK Negeri 1 Sedayu jika ditinjau dari konteksnya yang meliputi kesesuaian tujuan pembelajaran dengan kurikulum telah sesuai dan penyampaian kompetensi dasar pembelajaran belum bisa dilakukan semua.

Program pembelajaran mata pelajaran Pekerjaan Dasar Teknik Otomotif kelas X TKRO di SMK Negeri 1 Sedayu jika ditinjau dari masukannya yang meliputi kualifikasi dan pengalaman guru mata pelajaran PDTO telah sesuai Permendikbud Nomor 34 tahun 2018 pada Lampiran V Bab III, motivasi siswa masuk dalam kategori cukup baik, ketersediaan sarana dan prasarana di ruang kelas masuk kategori cukup dan ketersediaan alat praktik PDTO masuk dalam kategori sangat baik.

Program pembelajaran mata pelajaran Pekerjaan Dasar Teknik Otomotif kelas X TKRO di SMK Negeri 1 Sedayu jika ditinjau dari prosesnya yang meliputi penggunaan media masuk dalam kategori cukup baik, penggunaan metode oleh guru masuk dalam kategori cukup baik, pemanfaatan sumber belajar masuk dalam kategori cukup baik, dan keterlaksanaan langkah pembelajaran dengan pembelajaran masuk dalam kategori sangat baik.

Program pembelajaran mata pelajaran Pekerjaan Dasar Teknik Otomotif kelas X TKRO di SMK Negeri 1 Sedayu jika ditinjau dari produknya yang meliputi pencapaian belajar siswa 
pada tugas 1 dengan persentase ketuntasan 41,667\% dan tugas 2 dengan persentase ketuntasan $54,360 \%$.

Berdasarkan hasil penelitian yang diperolah, kiranya peneliti dapat memberikan saransaran kepada pihak sekolah dan pihak-pihak yang terkait dalam penelitian ini, demi keberhasilan program pembelajaran Pekerjaan Dasar Teknik Otomotif di SMK Negeri 1 Sedayu. Saran dari peneliti antara lain sebagai berikut:

Diharapkan guru program pembelajaran PDTO dalam menyusun perangkat pembelajaran berupa RPP dirancang lebih mendetail pada bagian kompetensi dasar pembelajaran, terutama pada kompetensi keterampilan. Dalam penyampaian kompetensi dasar pembelajaran, diharapkan guru tetap memprioritaskan proses pembelajaran sehingga waktu yang terbuang menjadi sedikit dan dapat diminimalir.

Pembinaan dan pelatihan guru sangat bermanfaat dalam meningkatkan pengetahuan dan keterampilan guru. Diharapkan sekolah mengadakan kegiatan seperti pelatihan berkaitan bidang keahlian. Pelatihan bisa dilakukan dengan bekerja sama dengan pihak-pihak luar SMK Negeri 1 Sedayu. Kecenderungan motivasi siswa mengikuti program pembelajaran masih dalam katogori cukup baik, hal tersebut dapat ditingkatkan sehingga jumlah siswa yang memiliki motivasi tinggi meningkat. Selain memotivasi siswa dengan bercerita, diharapkan guru bisa memanfaatkan video motivasi sebagai variasi sehingga siswa tidak merasa bosan. Sarana dan prasarana di ruang kelas sudah mencukupi dan masuk dalam kategori baik. Terdapat beberapa sarana dan prasarana masih belum ada misalnya lambing negara, foto prseidan, dan wakil presidan, diharapkan pihak sekolah memenuhi kekurangan tersebut. Selain itu diharapkan guru dan siswa sebagai pengguna ruang kelas harus terus menjaga kebersihannya, misalnya dengan membuat jadwal piket kelas dan guru sebagai pengontrol kebersihan kelas. Sarana dan prasarana praktik berupa alat praktik program pembelajaran PDTO masuk dalam kategori sangat baik. Meskipun begitu diharapkan siswa tetap menjaga K3 alat praktik dan menggunakannya sesuai SOP yang berlaku. Sebagai guru diharapkan tetap mengawasi siswa saat menggunakan alat praktik sehingga tidak terjadi kecelakaan kerja.

Diharapkan guru pengampu program pembelajaran PDTO lebih bervariasi dalam menggunakan metode dan media pembelajaran. Hal tersebut dilakukan agar pengalaman pembelajaran siswa lebih baik sehingga prestasi belajar siswa dapat ditingkatkan. Diharapkan siswa saat belajar terkait materi PDTO memanfaatkan sumber belajar yang disediakan disekolah misalnya meminjam buku di perpustakaan sekolah. Hal tersebut dilakukan agar siswa tidak terlalu tergantung pada internet dalam mencari suatu materi. Selain itu guru juga 
20 Agus Budiman, Zhafran Anas

diharapkan menganjurkan siswa untuk memakai berbagai sumber belajar agar menambah pengalaman belajar siswa.

Ketercapaian prestasi belajar peserta didik merupakan akibat dari proses pembelajaran yang melibatkan banyak faktor. Diharapkan guru selalu memotivasi peserta didik agar pola pikirnya dapat terbentuk untuk meningkatkan prestasi belajar. Meningkatkan keaktifan siswa melalui kegiatan pembelajaran didukung media dan metode pembelajaran yang menarik. Selain itu siswa juga diharapkan tidak hanya mengandalkan proses pembelajaran di dalam kelas tetapi juga memanfaatkan sumber belajar diluar kelas untuk meningkatkan pengetahuan.

\section{DAFTAR PUSTAKA}

Anonim. (1990). Peraturan Pemerintah Republik Indonesia Nomor 29 Tahun 1990 tentang pendidikan Menengah.

Anonim. (2003). Undang-Undang Republik Indonesia Nomor 20 Tahun 2003 Tentang Sistem Pendidikan Nasional.

Anonim. (2016). Pemerintah Perbanyak SMK dan Tingkatkan Kompetensi Pelaku Pendidikan

Kejuruan. Diakses Tanggal 28 September 2019 dari http://ksp.go.id/pemerintah-

perbanyak-smk-dan-tingkatkan-kompetensi-pelaku-pendidikan-kejuruan/index.html

Anonim. (2018). Slogan "SMK BISA!" Benarkah Lulus Bisa Langsung Kerja?. Diakses tanggal 28 September 2019 dari https://news.okezone.com/read/2018/12/07/65/1988338/slogan-smkbisa-benarkah-lulus-bisa-langsung-kerja

Anonim. (2019). Angka Pengangguran di DIY Alami Peningkatan. Diakses tanggal 29 September 2019 dari https://jogja.tribunnews.com/2019/02/19/angka-pengangguran-di-diy-alamipeningkatan

Anonim. (2019). Hasil Analisis UN jadi Landasan Peningkatan Kompetensi Pembelajaran. Diakses tanggal 1 Oktober 2019 dari https://gtk.kemdikbud.go.id/read-news/hasil-analisisun-jadi-landasan-peningkatan-kompetensi-pembelajaran

Arikunto, S. (1988). Penilaian Program Pendidikan. Jakarta: PT Bina Aksara.

Darmawan, D. (2014). Metode Penelitian Kuantitatif. Bandung: PT Remaja Rosdakarya.

Laksono, A. N. (2017). Evaluasi Program Pembelajaran Pendidikan Jasmani Di SMK Kesehatan Bina Tama Yogyakarta 2016/2017 Dengan Menggunakan Model CIPP. Skripsi. Yogyakarta: UNY.

Mardapi, D. (2008). Teknik Penyusunan Instrumen Tes Dan Nontes. Jakarta: Mitra Cendikia.

Mawarni, S. R. (2017). Evaluasi Pelaksanaan Pembelajaran Pengetahuan Bahan Tekstil Kelas X Busana Butik Di SMK Negeri 3 Klaten. Skripsi. Yogyakarta: UNY. 
Nurmalita, U. D. (2014). Evaluasi Pelaksanaan Pembelajaran Mengolah Makanan Kontinental Di SMK Negeri 3 Wonosari. Skripsi. Yogyakarta: UNY.

Sudjana, D. (2006). Evaluasi Program Pendidikan Luar Sekolah. Bandung: PT Remaja Rosdakarya.

Sugiyono. (2015). Metode Penelitian Pendidikan. Bandung: Alfabeta.

Sukardi (2014). Metodologi Penelitian Pendidikan. Jakarta: PT Bumi Aksara.

Sukmadinata, N. S. (2009). Metode Penelitian Pendidikan. Bandung: PT Remaja Rosdakarya. 
22 Agus Budiman, Zhafran Anas 